\title{
Methanol Extract of Coleus amboinicus (Lour) Exhibited Antiproliferative Activity and Induced Programmed Cell Death in Colon Cancer Cell WiDr
}

\author{
Farida Laila $\mathbb{D}^{1,2}$ Dedi Fardiaz, ${ }^{1}$ Nancy Dewi Yuliana $\mathbb{D}^{1}{ }^{1}$ M. Rizal M. Damanik, ${ }^{3}$ \\ and Fitriya Nur Annisa Dewi ${ }^{4}$ \\ ${ }^{I}$ Department of Food Science and Technology, Bogor Agricultural University, IPB Dramaga Campus, Bogor 16680, Indonesia \\ ${ }^{2}$ College of Vocational Studies, Bogor Agricultural University (IPB University), Jalan Kumbang No. 14, Bogor 16151, Indonesia \\ ${ }^{3}$ Department of Community Nutrition, Faculty of Human Ecology, Bogor Agricultural University, IPB Dramaga Campus, \\ Bogor 16680, Indonesia \\ ${ }^{4}$ Primate Research Center, Bogor Agricultural University, Jalan Lodaya II/5, Bogor 16151, Indonesia
}

Correspondence should be addressed to Farida Laila; flaila.safire@gmail.com and Nancy Dewi Yuliana; nancy_dewi@ipb.ac.id

Received 12 February 2019; Revised 22 July 2019; Accepted 30 July 2019; Published 25 January 2020

Academic Editor: Haile Yancy

Copyright (C) 2020 Farida Laila et al. This is an open access article distributed under the Creative Commons Attribution License, which permits unrestricted use, distribution, and reproduction in any medium, provided the original work is properly cited.

Coleus amboinicus (Lour) (CA) has been reported to possess many pharmacological activities. In this study, evaluation of cytotoxicity using brine shrimp lethality bioassay and MTT assay using WiDr cell lines was carried out. The expression of several genes responsible for programmed cell death of the methanol extract of CA was also investigated. The morphology of the cells undergoing apoptosis was detected using Hoechst staining assay. The gene expression of BAX, BCL2, P53, Caspase 1, 7, 8, and 9 of treated samples with different concentrations $(10,15,25 \& 50 \mu \mathrm{g} / \mathrm{ml})$ were measured with RT PCR. The phytochemical profiles were investigated using LC MS. The results showed that the lethality concentration $\left(\mathrm{LC}_{50}\right)$ of methanol extract using brine shrimp was $34.545 \mu \mathrm{g} / \mathrm{ml}$ and the extract exhibited good antiproliferative activity against cancer cells WiDr with $\mathrm{IC}_{50}$ value $(8.598 \pm 2.68 \mu \mathrm{g} / \mathrm{ml})$ as compared to standard drug 5-fluorouracil ( $\mathrm{IC}_{50}$ value $1.839 \pm 0.03 \mu \mathrm{g} / \mathrm{ml}$ ). There was apoptotic evidences from the morphology of treated cells. The expressions of $B A X, P 53$, and Caspase 9 were upregulated in lower concentration of the extract ( $10 \mathrm{and} 15 \mu \mathrm{g} / \mathrm{ml})$ but downregulated in higher concentration ( 25 and $50 \mu \mathrm{g} / \mathrm{ml}) . B C L 2$ as anti-apoptotic gene was downregulated in all concentrations. Caspase 1 and Caspase 7 were upregulated in high concentration $(25$ and $50 \mu \mathrm{g} / \mathrm{ml})$, but downregulated in lower concentrations. These data provide a mode of cell death for the methanol extract of CA in low concentrations corresponding to apoptosis with intrinsic pathway. Many valuable compounds identified including caffeic acid, rosmarinic acid, malic acid, eicosapentanoic acid, benserazide, alpha-linolenic acid, betaine, Salvanolic B, 4-hydroxibenzoic acid and firulic acid have been previously reported as being active agents against many cancer cells. This study suggested that CA might become an effective ingredient for health-beneficial foods to prevent colon cancer.

\section{Introduction}

Colorectal cancer is the third most common cancer in men and women and the fourth cause of death from cancer. Lifestyle factors like consuming red meat, processed meat, alcohol drinks, being overweight, or obese affect the risk of developing colorectal cancer [1].

The accumulation of genetic errors and some of which affect the control of apoptosis is the result of the increase in colorectal cancer [2]. Apoptosis is a programmed and regulated cellular process and triggered by physiological and pathological conditions [3]. The development of cancer is deeply affected by apoptosis process and its related pathway. Therefore, triggering apoptosis is one of the goals of cancer prevention [4]. The anticancer properties which have been revealed in many studies were the phytochemical content in plant responsible for apoptotic activity and have the potential to prevent, reverse and/or inhibit progression of cancer [5].

Coleus amboinicus (Lour) (synonym: Plectranthus amboinicus) belongs to the family of Lamiaceae is fleshy and highly aromatic. This plant has a common name as Mexican mint, Spanish thyme, Cuban oregano, or Indian borage. The leaves 
are used to add flavor to meat and bean dishes, especially in Carribean cuisine [6]. In Indonesia, this plant is called torbangun and has been used traditionally for hundreds of years by Bataknese people as a breast milk stimulant (a lactagogue) [7]. The pharmacological activities of Coleus amboinicus (Lour) have been widely studied. A study has reported that antihyperglycemic and anti-hyperlipidemic activity of torbangun in Streptozotocin induced diabetic rats [8]. Significant anticonvulsant activity of C. amboinicus in Swiss Albino Mice was also reported and the presence of flavonoids, alkaloids, and saponin in the extract may be responsible for this activity [9]. Plectranthus amboinicus Lour also had a cytotoxic effect on HeLa cells [10]. However, the activity and the mechanism of action against colon cancer cell in different concentrations of extract have not been performed.

The present study was designed to investigate the cytotoxicity and anticancer activity of methanol extract of Coleus amboinicus (CA) and also to describe the molecular mode of action in many concentrations of treated cells from the expression of several genes that were responsible for programmed cell death. The phytochemical contents were also investigated to evaluate the presence of important compounds that contributed to anticancer activity.

\section{Material and Methods}

2.1. Chemicals. Roswell Park Memorial Institute 1640 (RPMI1640), Phosphate Buffer Saline (PBS), 3-(4,5-dimethylthiazol-2yl)-2,5-diphenyltetrazolium bromide (MTT), were purchased from Sigma Aldrich chemical Company (St. Louis, MO, USA). $100,000 \mathrm{mg} / \mathrm{L}$ streptomycin and $100 \mathrm{x}$ antibiotic solution (100,000 U/I of penicillin), trypsin, acetone, hexane, 5-fluorouracil, formaldehyde, potassium chromate, and DMSO were purchased from The Merck Company (Germany). Sea sand (methanol washed 20-35 mesh) was purchased from Waco (Japan). Primer gene caspase 3/7, 8, 9, Bax, Bcl-2, housekeeping gene $\beta$-actin and 553 were purchased from Integrated DNA Technologies (Singapore). RNEeasy minikit was purchased from Qiagen (Singapore). Superscript III RT was purchased from Invitrogen (Singapore), SsoFast Evagreen Mastermix was purchased from Bio-Rad Laboratories (Singapore). Nuclease free water DEPC-treated PCR grade and Hoechst 33342 were purchased from Thermo Fisher Scientific (Singapore).

2.2. Collection and Extraction the Plant Material. Coleus amboinicus leaves were collected from Bogor Agricultural University Teaching Farm. The samples were freeze dried for 48 hours and grinded using Knife Mill Grindomix GM 200 at $10 \times 1000 \mathrm{rpm}$ for $20 \mathrm{~s}$. In brief, Accelerated solvent Extractor system (Dionex ASE 350) was used to extract the samples using methanol. For solvent evaporation, a centrifugal evaporator (CVE-200D EYELA) was employed.

2.3. Brine Shrimp Cytotoxicity Study. The cytotoxicity of CA was conducted using Brine Shrimp Lethality Assay (BSLA) by the method of Meyer et al. [11] with several modifications. Brine shrimp eggs (Artemia Salina Leach) were permitted to hatch as larvae (nauplii) in artificial sea water under light and good aeration. After $48 \mathrm{~h}$, the larvae were transferred to plate- 24 well plates and added with $1.0 \mathrm{ml}$ sea water. The solution of extract was added until the concentration extract in wells of 1000, 500, $250,125,50$, and $10 \mu \mathrm{g} / \mathrm{ml}$. Negative control was made by using $2 \mathrm{ml}$ artificial seawater without adding the extract. Potassium chromate $\mathrm{K}_{2} \mathrm{CrO}_{4}$ (Sigma Aldrich, St. Louis, MO, USA) was used as positive control with concentrations of 5.0, 10.0, 15.0, 20.0 , and $25.0 \mu \mathrm{g} / \mathrm{ml}$ in artificial sea water. The numbers of surviving larvae in each well were counted after $24 \mathrm{~h}$. The concentration that killed $50 \%$ of the nauplii $\left(\mathrm{LC}_{50}\right)$ and $95 \%$ confidence interval were calculated by Graphad using Probit analysis. The plant samples were weight three times and the procedure was performed in triplicate for each plant sample.

2.4. Cell Culture. WiDr cell lines were obtained from Primate Center Research, Bogor Agricultural University and cultured in Roswell Park Memorial Institute 1640 (RPMI-1640) (Sigma Aldrich, St. Louis, MO, USA) and supplemented with (5\% PBS penicillin and $1 \%$ streptomycin (Merck Company Germany) at $37.0^{\circ} \mathrm{C}$ and $5 \% \mathrm{CO}_{2}$. Based on the chromosomes and isozymic evidence, the cell line $\mathrm{WiDr}\left(\mathrm{ATCC}^{\otimes} \mathrm{CCL}-218^{\mathrm{Tm}}\right.$ ) is a derivative of another colon cancer cell line, HT-29 (ATCC ${ }^{\circledR}$ HTB-38 $^{\text {tM }}$ ) [12].

2.5. Cancer Cell Viability Assay. The antiproliferative activity of methanol extract of CA was studied using MTT assay. Cells that have undergone confluence were cultured, and the media were removed and the flask was cleaned from the media using $10 \mathrm{ml}$ PBS and after that PBS was removed from the flask. $5 \mathrm{ml}$ of Trypsin $(0.125 \%)$ was added to the flask and incubated at $37^{\circ} \mathrm{C}$ for $5 \mathrm{~min}$. The released cells from the substrate were inserted into a $15 \mathrm{ml}$ tube and centrifuged 1500 RPM for $5 \mathrm{~min}$. Supernatants were removed and cells were counted using the haemacytometer.

The cells were seeded in the density $2 \times 10^{4}$ cells/well and incubated overnight at $37^{\circ} \mathrm{C}$ and exposed to methanol extract of CA. The cells were treated with various concentrations $(1-100 \mu \mathrm{g} / \mathrm{ml}$ in $0.1 \% \mathrm{DMSO})$ to find the concentration of extract that inhibits $50 \%$ of the cell growth $\left(\mathrm{IC}_{50}\right.$ value). After incubation for $48 \mathrm{~h}$, the cells were washed with PBS to remove any traces of samples, then added with $10 \mu \mathrm{l}$ of $5 \mu \mathrm{g} / \mathrm{ml}$ MTT and incubated for $4 \mathrm{~h}$ at $37^{\circ} \mathrm{C}$ and $5 \% \mathrm{CO}_{2}$. Finally, the medium was removed and $100 \mu$ l of $95 \%$ ethanol was added to dissolve the formazan crystals. The plate was analyzed by using a microplate reader at $595 \mathrm{~nm}$ (Thermo Fisher, Waltham, MA, USA). The inhibition of the samples to WiDr cell lines was calculated using formula:

$$
\% \text { inhibition }=\frac{\text { ODsample }- \text { ODcontrol }}{\text { ODcontrol }} \times 100 \text {. }
$$

2.6. Detection of Apoptosis Using Hoechst Staining Method. WiDr cells were seeded at a density 5000 cells/well into the Chamber slide system 8 well. The cells were treated with methanol extract and 5-fluorouracil at 5 and $15 \mu \mathrm{g} / \mathrm{ml}$ and negative control (without sample) and incubated at $37^{\circ} \mathrm{C}$ and $5 \% \mathrm{CO}_{2}$ for $48 \mathrm{~h}$. The cells were washed with $500 \mu \mathrm{l}$ PBS twice followed by fixation with $10 \%$ formaldehyde and incubated for $1 \mathrm{~h}$ and then washed again with PBS. The cells were stained with $100 \mu \mathrm{l}$ Hoechst 33258 which has been diluted $1000 \times$, and then incubated for $30 \mathrm{~min}$ at room temperature, and washed again with PBS. The chromatin structure of the cells was 
TABLE 1: Primer sequences apoptosis related genes.

\begin{tabular}{|c|c|}
\hline Gene & Forward and reverse primer \\
\hline$B C L 2 F^{*}$ & $5^{\prime}$ - GCT CTA AAA TCC ATC CAG - $3^{\prime}$ \\
\hline$B C L 2 R^{*}$ & $5^{\prime}$ - CCT СТC CAT CAT CAA CTT - $3^{\prime}$ \\
\hline$B A X F^{* *}$ & $5^{\prime}$ - CCC GAG AGG TCT TTT TCC GAG -3' \\
\hline$B A X R^{* *}$ & $5^{\prime}$ - CCA GCC CAT GAT GGT TCT GAT - $3^{\prime}$ \\
\hline Caspase $8 F^{*}$ & $5^{\prime}$ - AGA GTC TGT GCC CAA ATC AAC - $3^{\prime}$ \\
\hline Caspase $8 R^{*}$ & $5^{\prime}$ - GCT GCT TCT CTC TTT GCT GAA -3' \\
\hline Caspase $1 F^{* *}$ & $5^{\prime}$ - CCT TCA AGG ACC TTG TCT GTT TAG -3' \\
\hline Caspase $1 R^{* *}$ & $5^{\prime}$ - GAG GGA TTA CCC AAC TGT GAG - $3^{\prime}$ \\
\hline Caspase $9 F^{* *}$ & $5^{\prime}$ - GAA TGA CGT GAA ACA CGA CAG - $3^{\prime}$ \\
\hline Caspase $9 R^{* *}$ & $5^{\prime}$ - TTA ACG GCA TCC CCC ACT TAG -3' \\
\hline Caspase $7 F^{* *}$ & 5' - GCAGCGCCGAGACTTTTAG-3' \\
\hline Caspase $7 R^{* *}$ & $5^{\prime}$ - GCTGCAGTTACCGTTCCCAC-3' \\
\hline TP53 $F^{* *}$ & $5^{\prime}$ - CCG CAG TCA GAT CCT AGC - $3^{\prime}$ \\
\hline TP53 $R^{* *}$ & $5^{\prime}$ - AAT CAT CCA TTG CTT GGG ACG -3' \\
\hline$A C T B F^{* *}$ & $5^{\prime}$ - AGAGCTACGAGCTGCCTGAC - $3^{\prime}$ \\
\hline$A C T B R^{* *}$ & $5^{\prime}$ - AGCACTGTGTTGGCGTACAG - $3^{\prime}$ \\
\hline
\end{tabular}

observed by fluorescence microscopy (Nikon Optivat-2) with $365 / 460 \mathrm{~nm}$ excitation/emission that connected with Digital Imaging System (Dino eye Software, Anmo Taiwan).

2.7. Gene Expressions. The expressions of genes that related to apoptosis were measured by Real time PCR. The WiDr cells were seeded in 12-well plates with RPMI 1640 and $10 \% \mathrm{PBS}$ and incubated at $37^{\circ} \mathrm{C}$ and $5 \% \mathrm{CO}_{2}$ for $24 \mathrm{~h}$. After that, the cells were treated with methanol extract at $10,15,25$, and $50 \mu \mathrm{g} / \mathrm{ml}$ concentration, untreated cells as a negative control and 5-fluorouracil in $\mathrm{IC}_{50}$ concentration as positive control, and then incubated for $48 \mathrm{~h}$. The extraction of RNA from treated and untreated cells was done using Commercial RNeasy mini kit (Qiagen, Germany). The quantity of RNA was evaluated by Nanodrop 2000C UV Spectrophotometer. The total RNA was reversed to cDNA by using Superscript III First Strand Synthesis System for RT-PCR. The gene expression levels were normalized with $\beta$-actin reference gene. The specific primers including BAX, BCL2, P53, Caspase 1, 7, 8, and 9 used in the real time PCR technique was carried out using SSo fast evagreen Supermix according to the manufacturer's protocols. Primer sequences and annealing temperature for quantitative PCR are shown in Table 1. Melting curves were checked to validate the PCR specificity. The relative expression of each gene was calculated using the $2^{-\Delta \Delta C t}$ method.

2.8. Phytochemical Profiles. The chemical composition of methanol extract of CA was determined using LC UHPLC Vanquish Tandem Q Exactive Plus Orbitrap HRMS (ThermoScientific). The sample was separated on a column of Accucore phenyl hexyl, $100 \times 2.1 \mathrm{~mm}, 2.6 \mu \mathrm{m}$. The flow rate was set at $0.3 \mathrm{ml} / \mathrm{min}$, using $\mathrm{H}_{2} \mathrm{O}+0.1 \%$ formic acid (A) and acetonitrile (B) as an eluent. The gradient was set at $0-1.5 \mathrm{~min}$ of $5 \% \mathrm{~B}, 1.5-9 \mathrm{~min}$ of $(5-9 \% \mathrm{~B}), 9-13 \mathrm{~min}$ of (10-20\% B), $13-17 \mathrm{~min}$ of $(20-28 \% \mathrm{~B}), 17-23 \mathrm{~min}(28-70 \%$ B), 23-26 min (70-95\% B), 26-29 (95\% B), 29-32 (5\% B). The detections of compounds were performed with mass range at $80-2000 \mathrm{~m} / \mathrm{z}$. The chemical compounds were identified using ThermoScientific ${ }^{\text {mit }}$ Compound Discoverer ${ }^{\mathrm{mm}}$ software.

2.9. Statistical Analysis. The $\mathrm{LC}_{50}$ value of BSLA test using Probit analysis and $\mathrm{IC}_{50}$ of antiproliferative cells using MTT assay were determined by Graphad 8.01 (GraphPad Software, San Diego, CA, USA). The Gene expression results were determined using One Way ANOVA with Dunnet's test to evaluate the significance of differences in fold changes between cell with treatment and control. The statistical significance was set at $p<0.05$.

\section{Results and Discussion}

\subsection{Cytotoxicity Using Brine Shrimp Lethality Assay} (BSLA). The preliminary step of this study was to determine the cytotoxicity of methanol extract of CA using BSLA. The result showed, the methanol extract of CA caused an increase in \% mortality of shrimp in a dose dependent manner (Figure 1). One hundred percent mortality was observed at $1000 \mu \mathrm{g} / \mathrm{ml}$ and above. The result of lethality concentration $\left(\mathrm{LC}_{50}\right)$ of extract using Probit test was $34.545 \mu \mathrm{g} / \mathrm{ml}$ with $95 \%$ confidence interval of 0.731 to 1.432 . This result was higher than positive control potassium chromate $\left(\mathrm{LC}_{50} 5.520 \mu \mathrm{g} / \mathrm{ml}\right)$. A previous study suggested that $\mathrm{LC}_{50}$ of the extract or pure compounds in the brine shrimp test less than $100 \mu \mathrm{g} / \mathrm{ml}$ is categorized as a potential cytotoxic and toxic substance [13]. Based on the result, the $\mathrm{LC}_{50}$ value of methanol extract of CA was fallen to its criteria and indicated the presence of potent cytotoxic compounds and probably antitumor agents in the methanol extract of CA.

Brine Shrimp Lethality Assay has been suggested as a valid method of evaluation of cytotoxicity and it can be extrapolated for cell lines toxicity and tumor activity [14]. A previous study has used BSLA for preliminary screening to find the cytotoxic activity of Markhamia tomentosa before cytotoxicity test using cell lines [15]. Another study also investigated the cytotoxicity of the rhizome of several medicinal plants using BSLA to search which rhizome can be used as a source of cytotoxic agent [16]. The cytotoxic activity of different extracts of cyanthea species using several solvent was also evaluated using BSLA and it was found that ethanol extract was more effective against brine shrimps and the result was subjected to proliferation assay in the cancer cell [17]. BSLA is only for preliminary assessment of toxicity and have been suggested for screening pharmacological activities of plant extract [18]. Therefore, for more precise evaluation of cytotoxic effect, an in vitro anticancer activity test using cell lines should be used.

3.2. Antiproliferative Activity. The further study was conducted to determine the inhibition of cell proliferative activity against WiDr cells of methanol extract of CA and standard cytotoxic drug 5-fluorouracil as positive control in various concentrations $(0-100 \mu \mathrm{g} / \mathrm{ml})$ using viability assay. The result of $\mathrm{IC}_{50}$ value of the extract from the curve of \% inhibition versus concentration was $8.598 \pm 2.68 \mu \mathrm{g} / \mathrm{ml}$ [19]. These findings suggested that the methanol extract of CA exhibited 


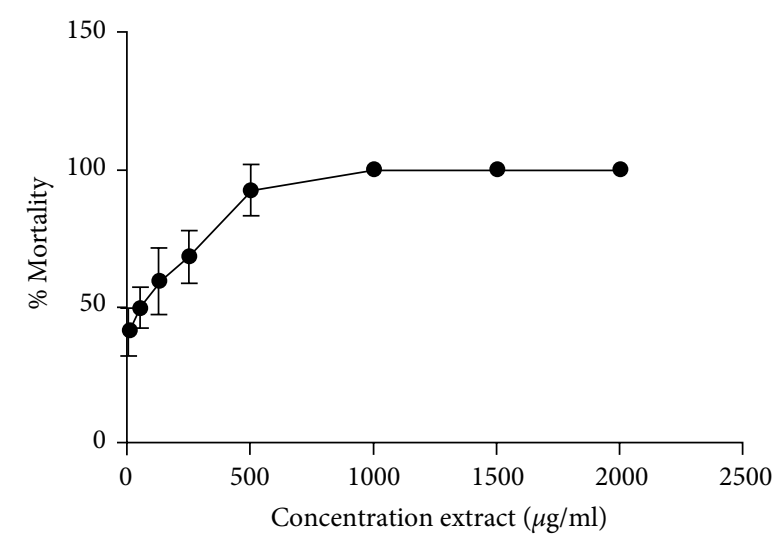

FIGURE 1: Mortality percentage (\%) curve of brine shrimp exposed to different concentrations of methanolic extract of Coleus amboinicus.

anti-proliferative activity in WiDr cancer cells and has a potential as chemotherapeutic agents. A previous study has demonstrated anti-proliferative effect of $P$. amboinicus leaves using MTT assay on MCF-7 human mammary cancer cells with the most active fraction was from chloroform fraction $\left(\mathrm{IC}_{50}\right.$ value of $2.46 \mu \mathrm{g} / \mathrm{ml}$ ) and the hexane fraction was $8.85 \mu \mathrm{g} /$ $\mathrm{ml})[10]$.

The control positive of the MTT assay study was using 5-fluorouracil (5-FU). We found the $\mathrm{IC}_{50}$ value of 5-FU was $1.839 \pm 0.03 \mu \mathrm{g} / \mathrm{ml}$. From this result, we suggest that the inhibition of cell proliferative activity of 5-FU was higher than the extract of CA. 5-FU is a common drug used for the treatment of various cancers, including colorectal and breast cancer [20]. 5-FU can inhibit the progression of cancer cells by targeting thymidylate synthase enzyme and promote cell cycle arrest and apoptosis [21]. The side effect of 5-FU to its cytotoxicity were serious and only $10-15 \%$ of patients with colorectal cancer could positively respond to 5-FU treatment [21]. There were many studies which combine natural compounds with 5-FU to enhance anti-proliferative activity and reduce 5-FU doses. Previous study reported the combination of 5-FU with Asian ginseng berry polysaccharide could reduce 5-FU doses and increase the anti-proliferative activity of colorectal cancer significantly [22].

3.3. Detection of Apoptosis. A further study was conducted to confirm the pro-apoptotic effect of methanol extracts of $C$. amboinicus. Identification of specific morphological structures was used in order to distinguish apoptotic cells from normal cells. Cell rounding and shrinkage, nuclear fragmentation, membrane blebbing, condensation of chromatin, and apoptotic body formation were identified in apoptotic cells [23]. Florescent images of WiDr cells were treated with Hoechst 33342 after 24-h incubation with 5-fluorouracil and the methanol extracts of CA at different concentrations are shown in Figure 2. The WiDr cells treated with all concentrations of methanol extract of CA showed typical characteristics of apoptosis with clear blue light colony implying DNA fragmentation in the nucleus which indicates apoptosis, and it was seen that the apoptotic effect enhanced at higher doses. The results were compared with positive control 5-FU, which showed a higher apoptotic effect in all concentrations. Hoechst staining indicated apoptotic cell to have shrunken, condensed, and also fragmented after exposure of the extract and 5-F for $24 \mathrm{~h}$. This contrast with the untreated cells showed a low fluorescence, normal nuclei and dispersed chromatin. These results suggest that CA and 5-F induces apoptosis of WiDr cell might contribute to reduce cell viability.

The apoptosis involves several types of mechanisms which include chromatin condensation, the fragmentation of DNA to form vesicles known as "apoptotic bodies". The reason why apoptotic bodies are not easy to detect and only seen under special condition is because phagocytic cells usually engulf apoptotic cells before apoptotic bodies occur.

3.4. Gene Expression. The further study was designed to find the mechanism of apoptosis by evaluating the changes in the expression level of apoptosis-related genes. This study is important for the development of treatment strategies against colon cancer. Changes in expression level of apoptosis-related genes such as P53, BAX, BCL2, Caspase 1, 7, 8, and 9 which had been treated with methanol extract of CA at concentrations of $10,15,25$, and $50 \mu \mathrm{g} / \mathrm{ml}$ were investigated using Real Time PCR to investigate the mechanism of action. Beta actin was served as the housekeeping control in all experiments. We also compared the expression of all related genes to the expression of 5-fluorouracil at $\mathrm{IC}_{50}$ concentration. The results of gene expression data a shown in Table 2.

Figure 3(a) shows significant upregulation of $\mathrm{p} 53$ in $\mathrm{WiDr}$ cell treated with $15 \mu \mathrm{g} / \mathrm{ml}$ to control, but downregulated at 25 and $50 \mu \mathrm{g} / \mathrm{ml}$ concentrations. One of the most important molecules in determining oncogenic transformation from the cancer treatment is tumor suppressor protein $\mathrm{p} 53$. More than $50 \%$ of human cancers related to the defect in this gene $[3,24]$. The over-expression of p53 is required for the execution of apoptosis of cancer cells. From this result, we concluded that the mechanism of cells death corresponds to apoptosis only at low concentrations, but it was not happening at higher concentrations.

Figures 3(b) and 3(c) shows there was significant upregulation of $B A X$ in WiDr cell treated with 10 and $15 \mu \mathrm{g} / \mathrm{ml}$ of CA methanol extract $(p<0.05)$ compared to control, but at 25 and $50 \mu \mathrm{g} / \mathrm{ml}$ the gene was downregulated. In contrast to $B A X$, the expression $B C L 2$ was significantly downregulated $(p<0.05)$ for all concentrations of the extract. The expression of $B A X$ and $B C L 2$ of 5-fluorouracil (5-FU) as positive control showed similar results with the extract at lower concentrations (10 and $15 \mu \mathrm{g} / \mathrm{ml})$.

Two common pathways in apoptosis are mitochondrial or intrinsic pathway and death receptor or extrinsic pathway. Mitochondrial pathway is regulated by Bcl-2 family protein consisting two main groups, namely pro-apoptotic protein and anti-apoptotic protein [3]. Apoptosis process is determined by the balance between pro-apoptotic and anti-apoptotic protein. Mitochondria dysfunction was achieved when the expression of antiapoptotic gene BCL2 was inhibited and pro-apoptotic gene BAX was up-regulated [25]. From the result, we found the methanol extract of CA initiated apoptosis process at lower concentrations because of the inhibition of BCL2 expression and over-expression of BAX. 


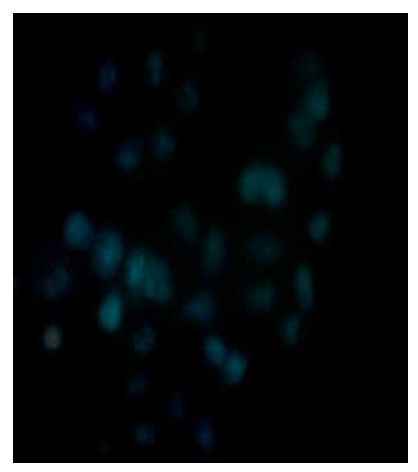

(a)

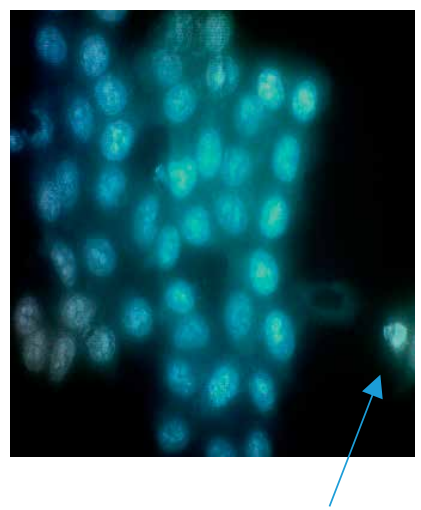

(d)

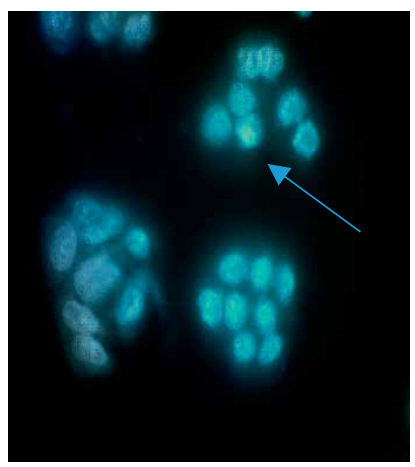

(b)

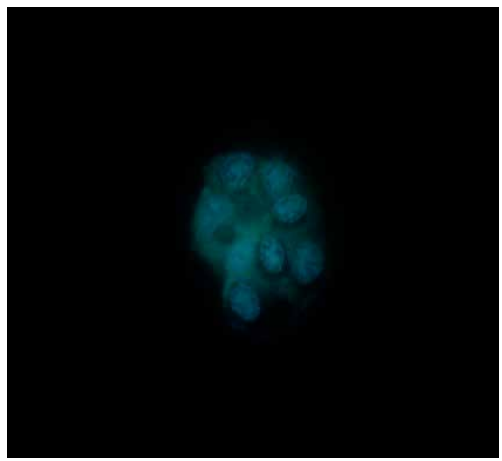

(e)

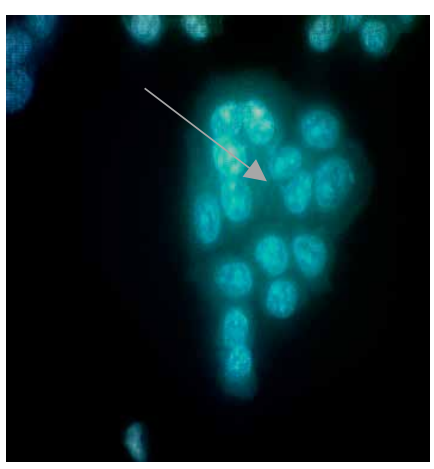

(c)

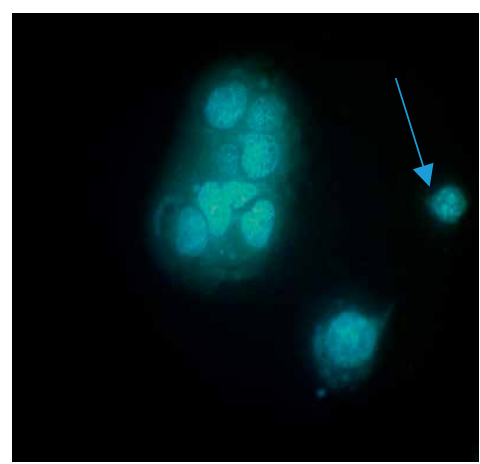

(f)

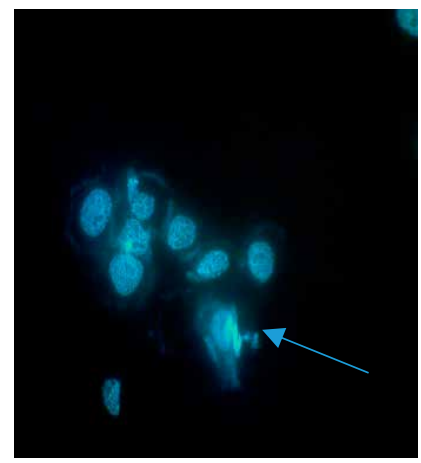

(g)

FIGURE 2: Morphological changes observed by Hoechst staining. (a) Untreated cells showed low fluorescent and normal structures. (b-d) are cells treated with 5 -fluorouracil at 5,15 , and $50 \mu \mathrm{g} / \mathrm{mL}$ concentrations respectively. (e-g) are cells treated with methanol extract of CA at 5 , 15 and $50 \mu \mathrm{g} / \mathrm{ml}$ concentrations respectively.

TABLE 2: The expression of apoptosis-related genes after cells treated with 5 -FU and methanol extract of CA at $10,15,25$, and $50 \mu \mathrm{g} / \mathrm{ml}$ concentrations.

\begin{tabular}{lccccccc}
\hline Treatment & & \multicolumn{5}{c}{ Fold change } \\
& Bax & Bcl-2 & p53 & Caspase 8 & Caspase 9 & Caspase 1 & Caspase 7 \\
\hline Control & $1.000 \pm 0.000^{\mathrm{a}}$ & $1.000 \pm 0.000^{\mathrm{a}}$ & $1.000 \pm 0.000^{\mathrm{a}}$ & $1.000 \pm 0.000^{\mathrm{a}}$ & $1.000 \pm 0.000^{\mathrm{a}}$ & $1.000 \pm 0.000^{\mathrm{a}}$ & $1.000 \pm 0.000^{\mathrm{a}}$ \\
$5-\mathrm{FU}$ & $1.800 \pm 0.170^{\mathrm{b}}$ & $0.236 \pm 0.025^{\mathrm{b}}$ & $3.285 \pm 1.135^{\mathrm{a}}$ & $0.325 \pm 0.005^{\mathrm{b}}$ & $4.785 \pm 0.545^{\mathrm{b}}$ & $0.445 \pm 0.015^{\mathrm{a}}$ & $0.235 \pm 0.005^{\mathrm{a}}$ \\
$10 \mu \mathrm{g} / \mathrm{ml}$ & $1.476 \pm 0.138^{\mathrm{b}}$ & $0.054 \pm 0.010^{\mathrm{b}}$ & $1.388 \pm 0.402^{\mathrm{a}}$ & $0.788 \pm 0.095^{\mathrm{b}}$ & $1.023 \pm 0.412^{\mathrm{a}}$ & $0.931 \pm 0.084^{\mathrm{a}}$ & $0.693 \pm 0.082^{\mathrm{a}}$ \\
$15 \mu \mathrm{g} / \mathrm{ml}$ & $1.665 \pm 0.035^{\mathrm{b}}$ & $0.807 \pm 0.062^{\mathrm{b}}$ & $1.887 \pm 0.355^{\mathrm{a}}$ & $0.710 \pm 0.000^{\mathrm{b}}$ & $1.263 \pm 0.157^{\mathrm{a}}$ & $1.130 \pm 0.024^{\mathrm{a}}$ & $1.020 \pm 0.109^{\mathrm{a}}$ \\
$25 \mu \mathrm{g} / \mathrm{ml}$ & $0.406 \pm 0.023^{\mathrm{b}}$ & $0.083 \pm 0.013^{\mathrm{b}}$ & $0.167 \pm 0.001^{\mathrm{a}}$ & $0.080 \pm 0.029^{\mathrm{b}}$ & $0.824 \pm 0.119^{\mathrm{a}}$ & $42.421 \pm 2.057^{\mathrm{b}}$ & $40.855 \pm 7.147^{\mathrm{b}}$ \\
$50 \mu \mathrm{g} / \mathrm{ml}$ & $0.773 \pm 0.078^{\mathrm{a}}$ & $0.043 \pm 0.008^{\mathrm{b}}$ & $0.050 \pm 0.008^{\mathrm{a}}$ & $0.046 \pm 0.001^{\mathrm{b}}$ & $0.825 \pm 0.111^{\mathrm{a}}$ & $34.253 \pm 9.917^{\mathrm{b}}$ & $37.888 \pm 11.806^{\mathrm{b}}$ \\
\hline
\end{tabular}

${ }^{\mathrm{a}} p>0.05$ versus control. ${ }^{\mathrm{b}} p<0.05$ versus control. 


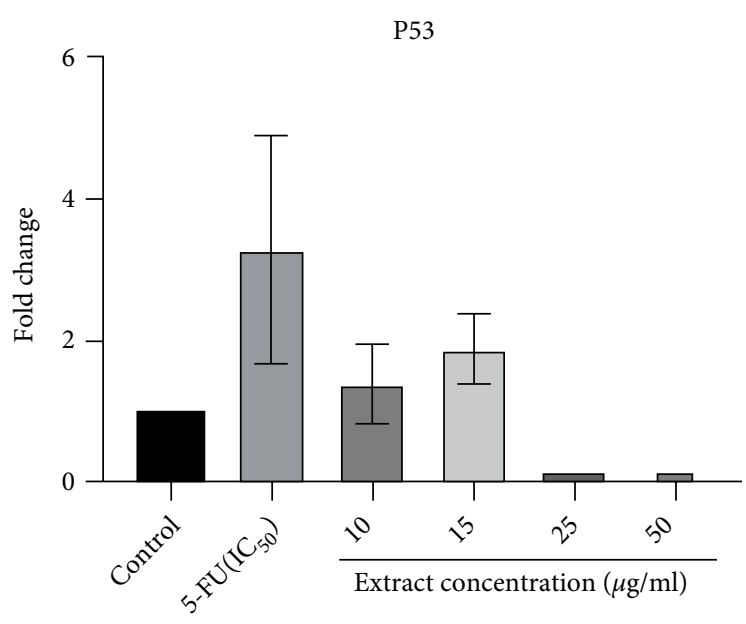

(a)

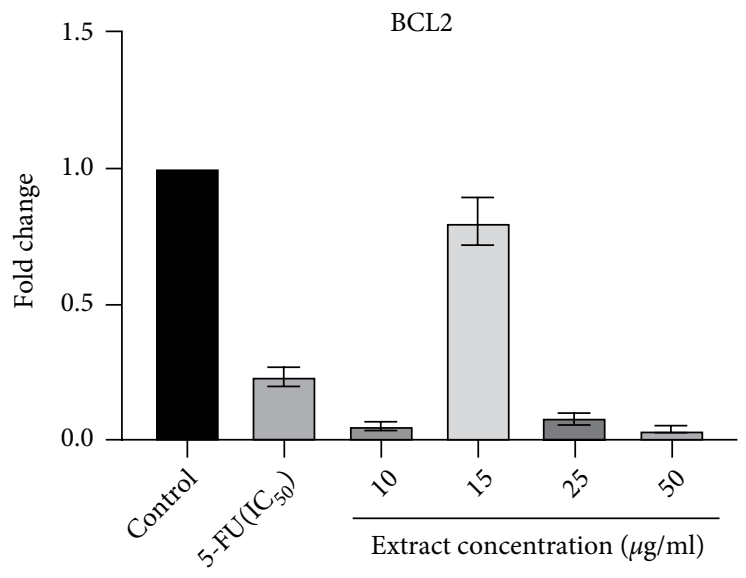

(c)

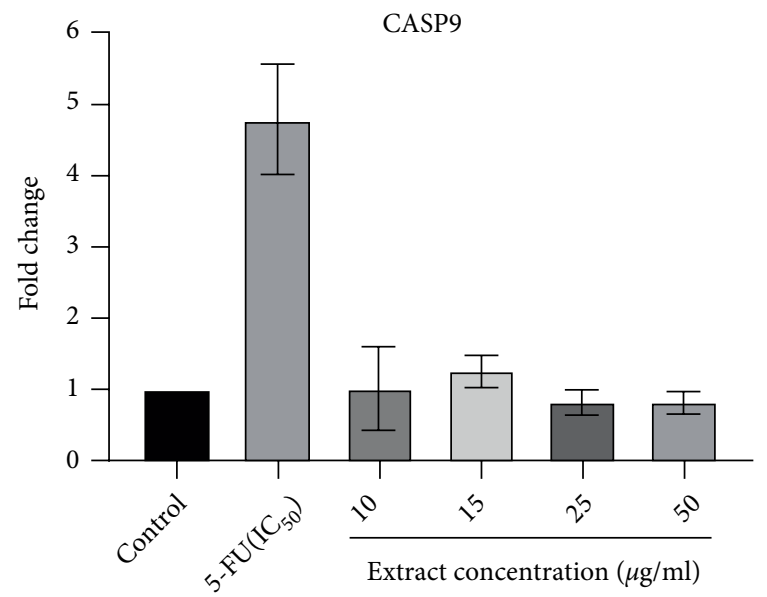

(e)

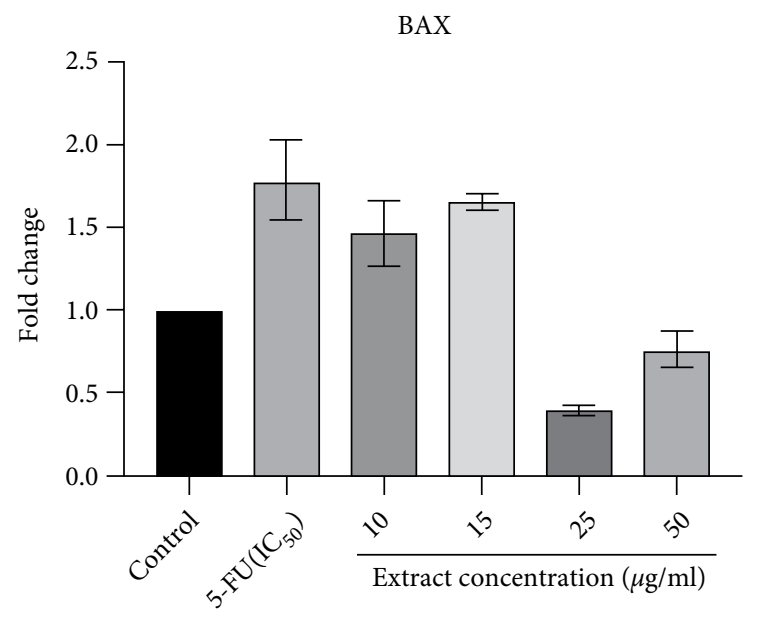

(b)

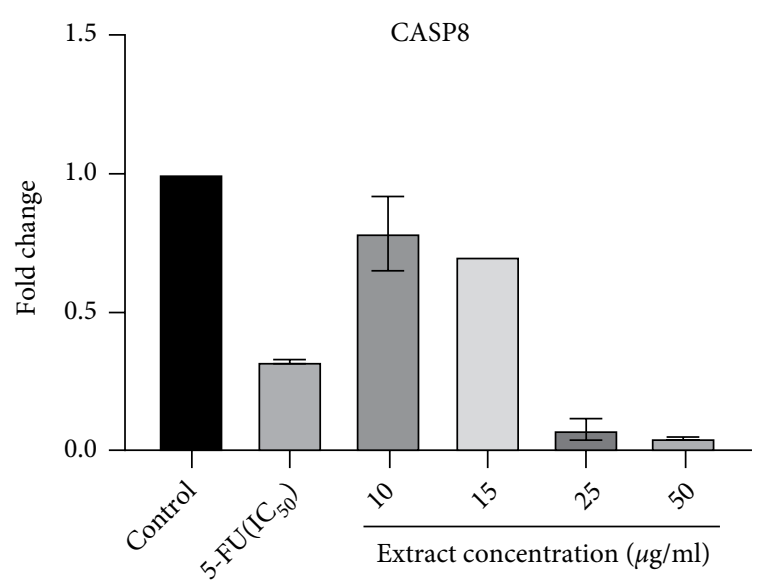

(d)

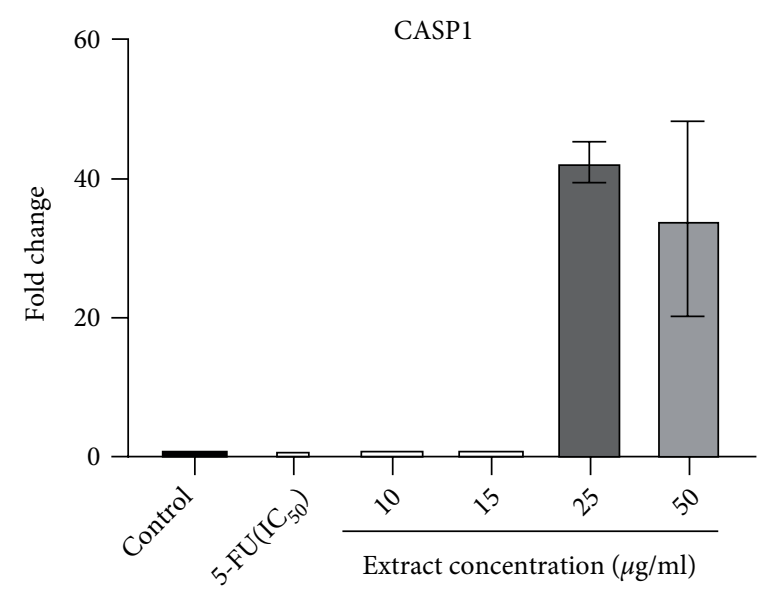

(f)

FIgure 3: Continued. 


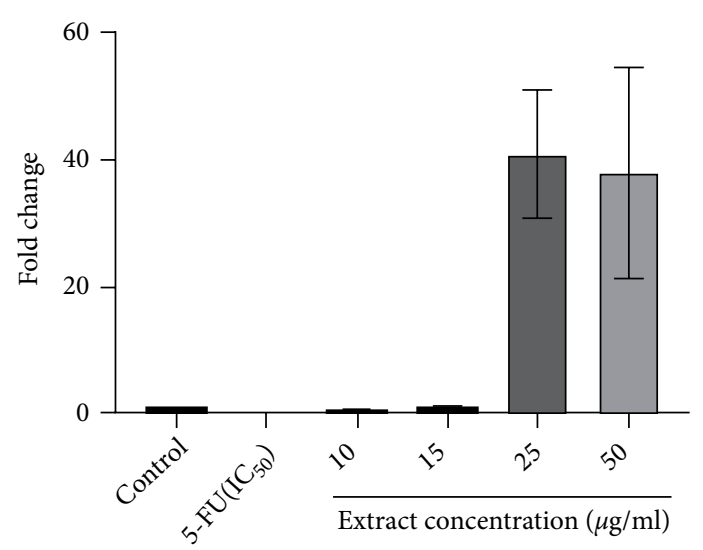

(g)

Figure 3: Gene expression of Bax (a); Bcl-2 (b); p53 (c); caspase 8 (d); caspase 9 (e); caspase 1 (f) and (g) caspase 7 of WiDr cells treated with methanol extract at concentrations $10,15,25$, and $50 \mu \mathrm{g} / \mathrm{ml}$ and compared to the expression of 5-fluorouracil (5-F) at IC50.

The expression of several caspases related to cell death was also investigated in this study. Activation of caspases is the final stage of apoptosis process. Caspases acted as the initiators and executioners and important to the mechanism apoptosis [3]. Figure 3(d) shows the expression of Caspase 8 was significantly downregulated for all concentrations $(p<0.05)$. Figure 3(e) shows upregulation of Caspase 9 in WiDr cell treated with 10 and $15 \mu \mathrm{g} / \mathrm{ml}$ of CA extract compared to control. On the other hand, Caspase 9 was downregulated at 25 and $50 \mu \mathrm{g} / \mathrm{ml}$. 5-FU also showed significant upregulation of Caspase 9 ( $p<0.05)$, but Caspase 8 was downregulated compared to control.

In extrinsic pathway, apoptosis is triggered by extracellular ligan-induced activation of death receptors which leads to activation of Caspase 8. Intrinsic or mitochondrial pathway is initiated within the cells and strongly regulated by a Bcl-2 family, which leads to activation of Caspase 9 [26]. Both pathways culminated the activation of "executioner" caspases, Caspase 3 and Caspase 7 [27]. The results of the expression of Caspase 8 and Caspase 9 in the methanol extract to WiDr cell suggested that the mechanism of apoptosis in low concentrations corresponded to intrinsic pathway. This result was also in line with 5 -fluorouracil at $\mathrm{IC}_{50}$ concentration. The diminished activity of Caspase 9 in higher concentration is possibly due to the other cascades related to apoptosis or perhaps following the other mechanism of programmed cell death. These results were also in line with the expression of $B A X$ and $P 53$ that upregulated for 10 and $15 \mu \mathrm{g} / \mathrm{ml}$ concentrations and downregulated in 25 and $50 \mu \mathrm{g} / \mathrm{ml}$ concentrations. The caspase activities in WiDr showed that at different concentrations, various caspases were activated.

Interestingly, in 25 and $50 \mu \mathrm{g} / \mathrm{ml}$ concentrations of the extract, Caspase 7 as the executioner was highly expressed. On the other hand, the expression of this gene was downregulated in lower concentration (Figure 3(f)). The result was possible because there might be caspase 3 as another executioner caspase was activated at lower concentrations. Caspase
8 and 9 can activate both Caspase 3 and 7 during intrinsic and extrinsic pathways respectively [28].

Many studies have suggested the induction of apoptosis related to colorectal cancer cells based on the expression of several genes. Thunder God Vine extract initiated apoptosis in HTB-39 colon cancer cells, which was linked with upregulated expressions of $B A X$ and downregulation of BCL2 [29]. A sulfated polysaccharide isolated from $C$. fulvescens inhibits the growth of HT-29 colon cancer cells and activated caspase 3, 8, and 9 [30]. The roots of Codonopis bulleynana Forest ex diels or Tsoong upregulated apoptosis-related genes such as caspase 3, caspase 6, and Apaf-1 in HCT116 and SW 480 colon cancer cells [31].

The expression of Caspase 1 as one of inflammatory caspases was also evaluated in this study. Figure 3(f) shows that Caspase 1 was downregulated compared to control at 10 and $15 \mu \mathrm{g} / \mathrm{ml}$. However, at 25 and $50 \mu \mathrm{g} / \mathrm{ml}$ concentrations, Caspase 1 was significantly upregulated $(p<0.05)$. It also happened to Caspase 7 which downregulated at 10 and $15 \mu \mathrm{g} / \mathrm{ml}$ concentrations, but upregulated very significantly at 25 and $50 \mu \mathrm{g} / \mathrm{ml}$. The result was also compared with 5 -fluorouracil and it was found that Caspases 1 and 7 were also downregulated at $\mathrm{IC}_{50}$ concentration. The activation of Caspase 1 is initiated by the formation of a cytosolic complex called "inflammasome" [32]. Therefore, there is the possibility that at high concentrations of CA methanol extract, the cells were not induced apoptosis but other programmed necrosis. In this study, we found that Caspase 7 was also upregulated significantly in 15 and $50 \mu \mathrm{g} / \mathrm{ml}$ just like Caspase 1 . We suggested there might be a connection between Caspase 1 and Caspase 7 in the inflammatory type of cell death. A study reported caspase 7 activation observed is known to induce activation of caspase 1 . On the other hand, activation of caspase 3 did not required induction of caspase 1 and the inflammasome [33].

Another study also reported that many anticancer agents at lower concentrations cause apoptosis while at higher doses they cause necrosis [34]. A subclass of another form of cell 

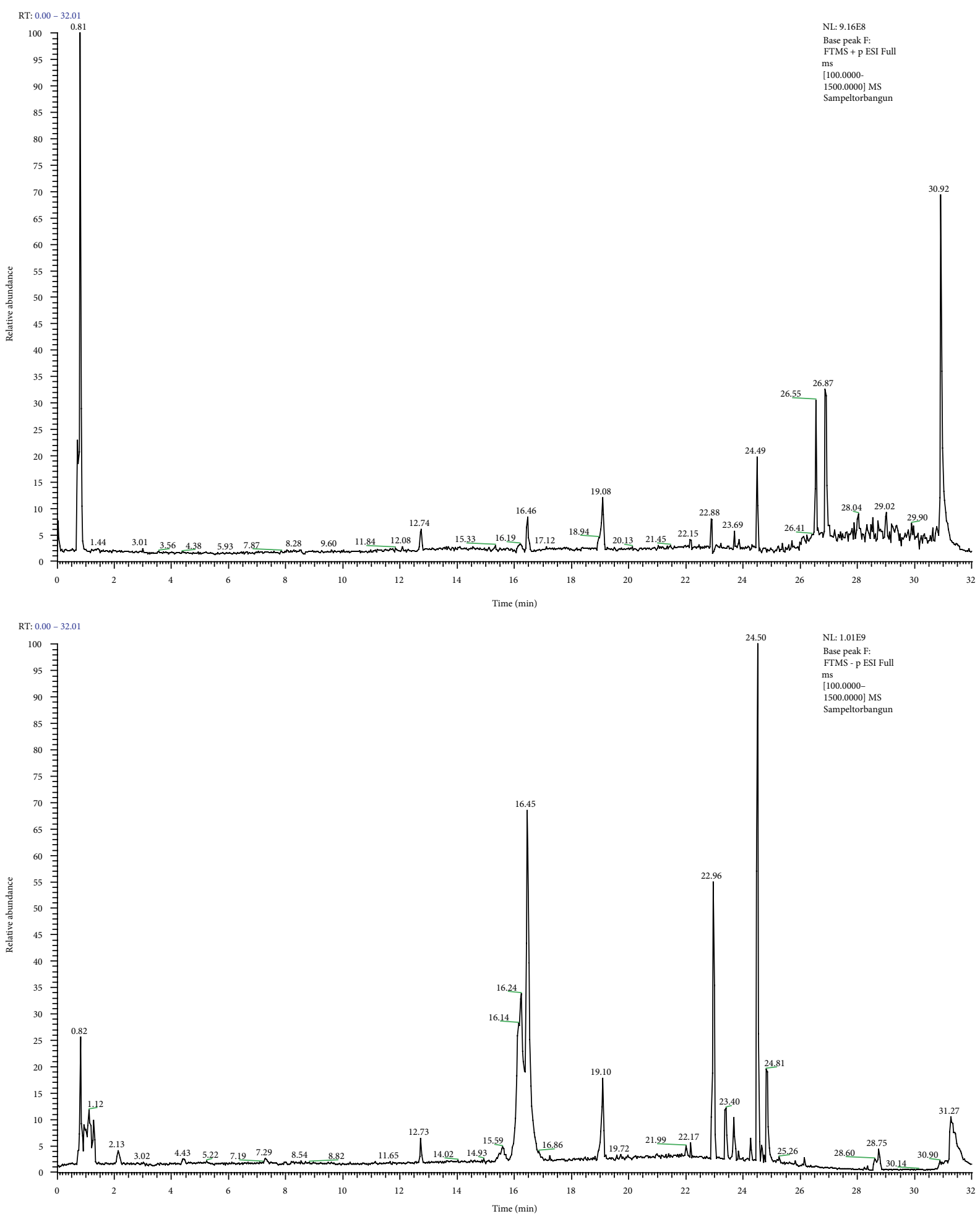

FIgURE 4: The Chromatogram of methanol extract of CA using Liquid Chromatography-Mass Spectrometry.

death, besides apoptosis that are controlled by specific pathways which morphologically discrete from apoptosis called programmed necrosis, has been defined recently [35]. Induction of the programmed necrosis could be useful when drug fails to induce apoptosis. For example, the ability to employ nonapoptotic cell death might provide new opportunities to control cell death and to destroy apoptosis resistant cancer cell [36]. From this study, we could not conclude the mechanism of cell death of the cancer cell lines treated with CA at high concentration and further studies are needed to validate the mechanism of action of other programed cell death. 


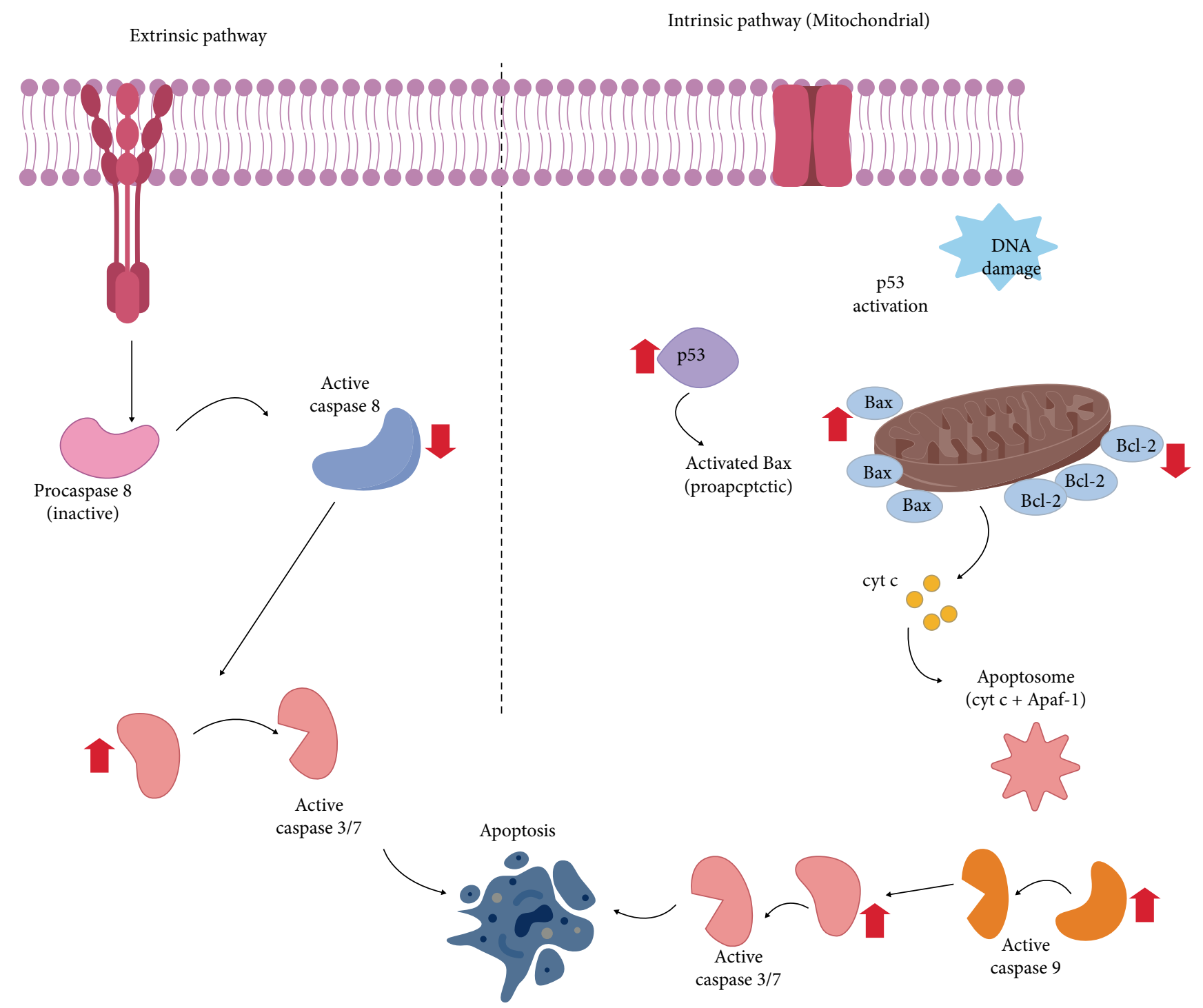

FIGURE 5: The proposed mechanism of apoptosis for the methanol extract of CA at 10 and $15 \mu \mathrm{g} / \mathrm{ml}$ concentrations.

3.5. Phytochemical Profiles of Methanol Extract of $C$. amboinicus. The LC MS/MS was used to investigate the chemical profiles of CA. The identified chemicals are shown in Table 3 and the chromatogram is shown in Figure 4. There were many important compounds in the extracts identified including caffeic acid, rosmarinic acid, malic acid, cis-5,8,11,14,17-eicosapentanoic acid (EPA), benserazide, a-linolenic acid, betaine, Salvanolic B, 4-hydroxybenzoic acid, and firulic acid. These compounds have been studied in many literatures for their anticancer activity.

Caffeic acid has been reported to possess anticancer activity through its pro-oxidant property. Caffeic acid treatments have enhanced ROS levels and altered mitochondrial membrane potential in HeLa and ME-180 cancer cells [37]. Rosmarinic acid anticancer activity in many cancer cell has been reviewed by Swamy et al. [38]. Eicosapentaenoid acid induced apoptosis by activating caspase-3, inhibit cyclooxygenase-2 (COX-2) resulting in inhibition of prostaglandin synthesis and prostaglandin-mediated inflammatory process
[39] Eiocosapentanoic acid (EFA) combined with other anticancer drugs caused a synergistic suppressor effect on TE-1 human esophageal cancer cell proliferations [40].

Benserazide, a selective HK2 inhibitor was able to suppress cancer growth in tumor-bearing mice and inhibit glycolysis in aerobic glycolytic colorectal cancer cell SW 480 [41]. Alphalinolenic acid is an n-3-polyunsaturated fatty acid (PUFA) having an effective role in prostate cancer. Dietary of $\alpha$ - linolenic acid may trigger an increase in ALA, EPA, DPA, and DHA levels and significant decresase in arachidonic acid level during the mice's growth stage [42]. Betaine intake inversely associated with colorectal cancer risk [43].

Salvianolic B (Sal-B) significantly inhibited the growth of retinoblastoma cell $\mathrm{HXO}-\mathrm{RB} 44$ and induced apoptosis with upregulation of caspase- 3 expression and the induction of cell cycle arrest [44]. Sal-B was a leading bioactive compound in Salvia Miltiorrhiza Bunge and in vitro analysis showed that Sal-B could significantly reduce cell viability and suppress the proliferation of MDA-MB-231 and MCF-7 cells [45]. 
TABLE 3: Phytochemicals of methanol extract of CA by Liquid Chromatography-Mass Spectrometry.

\begin{tabular}{|c|c|c|c|}
\hline No & Name & Formula & $\mathrm{RT}[\mathrm{min}]$ \\
\hline 1 & Rosmarinic acid & $\mathrm{C}_{18} \mathrm{H}_{16} \mathrm{O}_{8}$ & 16.501 \\
\hline 2 & 13,14-Dihydro-15-keto Prostaglandin J2 & $\mathrm{C}_{20} \mathrm{H}_{30} \mathrm{O}_{4}$ & 23.906 \\
\hline 3 & 7-Hydroxycoumarine & $\mathrm{C}_{9} \mathrm{H}_{6} \mathrm{O}_{3}$ & 19.616 \\
\hline 4 & L-(-)-Malic acid & $\mathrm{C}_{4} \mathrm{H}_{6} \mathrm{O}_{5}$ & 1.12 \\
\hline 5 & Pipecolic acid & $\mathrm{C}_{6} \mathrm{H}_{11} \mathrm{~N} \mathrm{O}_{2}$ & 0.886 \\
\hline 6 & cis-5,8,11,14,17-Eicosapentaenoic acid & $\mathrm{C}_{20} \mathrm{H}_{30} \mathrm{O}_{2}$ & 25.281 \\
\hline 7 & Ferulic acid & $\mathrm{C}_{10} \mathrm{H}_{10} \mathrm{O}_{4}$ & 15.391 \\
\hline 8 & Apigenin 7-O-glucuronide & $\mathrm{C}_{21} \mathrm{H}_{18} \mathrm{O}_{11}$ & 15.775 \\
\hline 9 & 15-Deoxy- $\Delta 12,14$-prostaglandin A1 & $\mathrm{C}_{20} \mathrm{H}_{30} \mathrm{O}_{3}$ & 25.554 \\
\hline 10 & 13,14-Dihydro-15-keto Prostaglandin J2 & $\mathrm{C}_{20} \mathrm{H}_{30} \mathrm{O}_{4}$ & 23.096 \\
\hline 11 & 4-Hydroxybenzoic acid & $\mathrm{C}_{7} \mathrm{H}_{6} \mathrm{O}_{3}$ & 4.444 \\
\hline 12 & $\alpha$-Lactose & $\mathrm{C}_{12} \mathrm{H}_{22} \mathrm{O}_{11}$ & 0.878 \\
\hline 13 & Apigenin 7-O-glucuronide & $\mathrm{C}_{21} \mathrm{H}_{18} \mathrm{O}_{11}$ & 15.974 \\
\hline 14 & Ferulic acid & $\mathrm{C}_{10} \mathrm{H}_{10} \mathrm{O}_{4}$ & 15.632 \\
\hline 15 & $(2 \alpha, 3 \beta, 19 \alpha)-2,3,19$-Trihydroxyolean-12-en-28-oic acid & $\mathrm{C}_{30} \mathrm{H}_{48} \mathrm{O}_{5}$ & 22.265 \\
\hline 16 & 1-Aminocyclohexanecarboxylic acid & $\mathrm{C}_{7} \mathrm{H}_{13} \mathrm{~N} \mathrm{O}_{2}$ & 0.882 \\
\hline 17 & Salvianolic acid B & $\mathrm{C}_{36} \mathrm{H}_{30} \mathrm{O}_{16}$ & 16.769 \\
\hline 18 & 15-Deoxy- $\Delta 12,14$-prostaglandin $\mathrm{A} 1$ & $\mathrm{C}_{20} \mathrm{H}_{30} \mathrm{O}_{3}$ & 24.459 \\
\hline 19 & Caffeic acid & $\mathrm{C}_{9} \mathrm{H}_{8} \mathrm{O}_{4}$ & 7.33 \\
\hline 20 & 9S,13R-12-Oxophytodienoic acid & $\mathrm{C}_{18} \mathrm{H}_{28} \mathrm{O}_{3}$ & 23.569 \\
\hline 21 & Caffeic acid & $\mathrm{C}_{9} \mathrm{H}_{8} \mathrm{O}_{4}$ & 16.21 \\
\hline 22 & 9-Oxo-10(E),12(E)-octadecadienoic acid & $\mathrm{C}_{18} \mathrm{H}_{30} \mathrm{O}_{3}$ & 23.983 \\
\hline 23 & Betaine & $\mathrm{C}_{5} \mathrm{H}_{11} \mathrm{~N} \mathrm{O}_{2}$ & 0.874 \\
\hline 24 & Caffeic acid & $\mathrm{C}_{9} \mathrm{H}_{8} \mathrm{O}_{4}$ & 16.491 \\
\hline 25 & $\alpha$-Linolenic acid & $\mathrm{C}_{18} \mathrm{H}_{30} \mathrm{O}_{2}$ & 24.954 \\
\hline
\end{tabular}

4-Hydroxybenzoic acid (4-HBA) inhibited cell proliferation of human K-562 leukemia cells and induced apoptosis with the inhibition of antiapoptotic activity of Bcl-2, Bcl-xl, and Mcl-1 [46]. 4 HBA also has anticancer activity in the MCF-7 breast cancer and induced apoptosis from the increased of expression of caspase- 3 and PARP Cleavage, which was associated with the promotion of $\mathrm{p} 53$ [47].

Treatment of Firulic acid isolated from Ferula Foetida decreased the viability, increased apoptosis, and suppressed the metastatic potential in breast cancer cell line MDA-MD-231 [48]. Ferulic acid significantly inhibited cell proliferation and induced arrest in G0/G1 phase of the cell cycle in Hela and Caski cells and also induced the cell cycle related protein expression of p53, P21 and reduced Cyclin D1 and cyclin E levels [49].

The phytochemical content of C. amboinicus or P. amboinicus has been characterized in many studies. Bhatt et al. [50], reported the major constituents of stem $P$. amboinicus in methanol extract were rosmarinic acid, caffeic acid, rutin, gallic acid, quercetin, and p-coumaric acid. Hemalatha et al. [51] who analyzed ethanolic extract of $P$. amboinicus leaves by GC-MS reported the major components were n-Hexadecanoic acid, thymol, 9-octadecenal (z), 10-heneicosane (c, t), and phytol. El-hawary et al. [52] also reported the major components in stems and roots of ethyl acetate extract of $P$. amboinicus grown in Egypt using UPLC-MS were caffeic acid, eriodyctiol, rosmarinic acid, coumaric acid, chrysoeriol and quercetin. Shubha and Bhatt [53] who analyzed the leaves using HPLC also reported that polyphenols and sugars were the dominant constituents and found chlorogenic acid, coumaric acid, and caffeic acid in appreciable concentrations. The solvent types, extraction technique, environmental condition of plant growth, and climate are several factors responsible for the variation of phytochemical content. From the result, we suggested that the presence of these bioactive compounds in CA would contribute to anticancer properties of this plant.

\section{Conclusion}

In conclusion, the present study demonstrates cytotoxicity of C. amboinicus to colon cancer. The extract showed potent anti-colon cancer activity against WiDr cells as compared to 5-flurouracil as a standard drug. The methanol extract of CA induces cell death at low concentrations mainly via apoptosis as upregulated several genes like BAX, P53 and also downregulated antiapoptotic gene like BCL2. A mode of cell death for the methanol extract of CA corresponded to apoptosis with intrinsic pathway in low concentrations as it upregulated Caspase 9 but downregulated Caspase 8. On the other hand, at high concentrations might correspond to another programmed cell death. Therefore, further study related to other programmed cell death is important to validate the mechanism of action. The result obtained from LC MS analysis indicated the existences of many valuable bioactive compounds that would be contributed to anticancer properties of CA. 
Coleus amboinicus (Lour) shows potential as chemotherapeutic agents for colon cancer and might become an ingredient for health-beneficial foods to prevent colon cancer.

\section{Data Availability}

The dataset used to support the funding of this study has been deposited in Mendeley Data (DOI: 10.17632/7trktkswrn.1).

\section{Conflicts of Interest}

The authors declare that they have no conflicts of interest.

\section{Acknowledgments}

The Authors acknowledge the School of College of Vocational Studies Bogor Agricultural University (IPB University), Food Research Institute National Agriculture and Food Research Organization Tsukuba Japan, SEAFAST Center Bogor Agricultural University and Primate Center Research, Bogor Agricultural University.

\section{References}

[1] World Cancer Research Fund/American Institute for Cancer Research, "Diet, Nutrition, Physical Activity and Colorectal Cancer, 2018," https://www.wcrf.org/dietandcancer.

[2] A. J. M. Watson, "An overview of apoptosis and the prevention of colorectal cancer," Critical Reviews in Oncology/Hematology, vol. 57, no. 2, pp. 107-121, 2006.

[3] R. S. Y. Wong, "Apoptosis in cancer: from pathogenesis to treatment," Journal of Experimental \& Clinical Cancer Research, vol. 30, no. 1, p. 87, 2011.

[4] P. N. Ansil, P. J. Wills, R. Varun, and M. S. Latha, "Cytotoxic and apoptotic activities of amorphophallus campanulatus (Roxb.) Bl. tuber extracts against human colon carcinoma cell line HCT-15," Saudi Journal of Biological Sciences, vol. 21, no. 6 , pp. 524-531, 2014.

[5] I. Borrás-Linares, A. Pérez-Sánchez, J. Lozano-Sánchez et al., "A bioguided identification of the active compounds that contribute to the antiproliferative/cytotoxic effects of rosemary extract on colon cancer cells," Food and Chemical Toxicology, vol. 80, pp. 215-222, 2015.

[6] NParks Flora \& Fauna Web, "Plectranthus amboinicus (Lour.) Spreng," https:/florafaunaweb.nparks.gov.sg/Special-Pages/ plant-detail.aspx?id=3717.

[7] R. Damanik, “Torbangun (Coleus amboinicus lour): a bataknese traditional cuisine perceived as lactagogue by bataknese lactating women in simalungun, North SumateraIndonesia," Journal of Human Lactation, vol. 25, no. 1, pp. 64-72, 2009.

[8] T. Suryowati, R. Damanik, and M. Bintang, "Antihyperlipidemic activity of torbangun extract (Coleus amboinicus lour) on diabetic rats induced by streptozotocin," IOSR Journal of Pharmacy, vol. 5, no. 5, pp. 50-54, 2015.

[9] P. Majumder, P. Bhattacharjee, "Investigation of phytochemicals and anti-convulsant activity of the plant Coleus amboinicus (Lour.)," International Journal of Green Pharmacy, vol. 7, no. 3, p. 211, 2013.
[10] W. Yulianto, N. Andarwulan, and P. E. Giriwono, J. Pamungkas, "HPLC-based metabolomics to identify cytotoxic compounds from Plectranthus amboinicus (Lour.) spreng against human breast cancer MCF-7cells," Journal of Chromatography B, vol. 1039, pp. 28-34, 2016.

[11] B. Meyer, N. Ferrigni, J. Putnam, L. Jacobsen, D. Nichols, and J. McLaughlin, "Brine shrimp: a convenient general bioassay for active plant constituents," Planta Medica, vol. 45, no. 5, pp. 31-34, 1982.

[12] T. R. Chen, D. Drabkowski, R. J. Hay, and M. Macy, "WiDr is a derivative of another colon adenocarcinoma cell line, HT-29," Cancer Genetics and Cytogenetics, vol. 27, no. 1, pp. 125-134, 1987.

[13] M. Firdaus, A. A. Prihanto and R. Nurdiani, "Antioxidant and cytotoxic activity of acanthus ilicifolius flower," Asian Pacific Journal of Tropical Biomedicine, vol. 3, no. 1, pp. 17-21, 2013.

[14] P. B. Udavant, S. V. Satyanarayana, and C. D. Upasani, "Preliminary screening of cuscuta reflexa stems for anti inflammatory and cytotoxic activity," Asian Pacific Journal of Tropical Biomedicine, vol. 2, no. 3, pp. S1303-S1307, 2012.

[15] B. Ibrahim, A. Sowemimo, L. Spies, T. Koekomoer, and M. van de Venter, O. A. Odukoya, "Antiproliferative and apoptosis inducing activity of markhamia tomentosa leaf extract on HeLa cells," Journal of Ethnopharmacology, vol. 149, no. 3, pp. 745-49, 2013.

[16] S. Hossain, G. Kader, F. Nikkon, and T. Yeasmin, "Cytotoxicity of the rhizome of medicinal plants," Asian Pacific Journal of Tropical Biomedicine, vol. 2, no. 2, pp. 125-127, 2012.

[17] N. Janakiraman and M. Johnson, "Ethanol extracts of selected cyathea species decreased cell viability and inhibited growth in MCF 7 cell line cultures," Journal of Acupuncture and Meridian Studies, vol. 9, no. 3, pp. 151-55, 2016.

[18] H. L. Raghavendra, T. R. Prashith Kekuda, N. C. Valleesha, and S. J. Sudharshan, "Screening for cytotoxic activity of methanol extract of Putranjiva roxburghii wall (Euphorbiaceae) seeds," Pharmacognosy Journal, vol. 2, no. 10, pp. 335-337, 2010.

[19] M. Bonesi, M. Brindisi, B. Armentano et al., "Exploring the anti-proliferative, pro-apoptotic, and antioxidant properties of Santolina Corsica Jord. \& Fourr. (Asteraceae)," Biomedicine and Pharmacotherapy, vol. 107, pp. 967-978, 2018.

[20] D. B. Longley, D. P. Harkin, and P. G. Johnston, "5-fluorouracil: mechanisms of action and clinical strategies," Nature Reviews Cancer, vol. 3, no. 5, pp. 330-338, 2003.

[21] L. Yuan, S. Zhang, H. Li et al., "The influence of gut microbiota dysbiosis to the efficacy of 5 -fluorouracil treatment on colorectal cancer," Biomedicine and Pharmacotherapy, vol. 108, pp. 184193, 2018.

[22] C. Z. Wang, L. Hou, J. Y. Wan et al., "Ginseng berry polysaccharides on inflammation-associated colon cancer: inhibiting $\mathrm{T}$ cell differentiation, promoting apoptosis, and enhancing the effects of 5-fluorouracil," Journal of Ginseng Research, 2019.

[23] S. R. Balusamy, H. Perumalsamy, M. A. Huq, and B. Balasubramanian, "Anti-proliferative activity of origanum vulgare inhibited lipogenesis and induced mitochondrial mediated apoptosis in human stomach cancer cell lines," Biomedicine and Pharmacotherapy, vol. 108, pp. 1835-1844, 2018.

[24] M. Oren and V. Rotter, "Introduction: P53-the first twenty years," Cellular and Molecular Life Sciences, vol. 55, no. 1, pp. 9-11, 1999. 
[25] J. Gross, M. McDonnell, and S. J. Korsmeyer, "BCL-2 family members and the mitochondria in apoptosis," Genes and Development, vol. 13, no. 15, pp. 1899-1911, 1999.

[26] M. E. Juan, I. Alfaras, and J. M. Planas, "Colorectal cancer chemoprevention by trans-resveratrol," Pharmacological Research, vol. 65, no. 6, pp. 584-91, 2012.

[27] K. McArthur and B. T. Kile, "Apoptotic caspases: multiple or mistaken identities?" Trends in Cell Biology, vol. 28, no. 6, pp. 475-493, 2018.

[28] S. Khazaei, N. Esa, M. V. Ramachandran et al., "In vitro antiproliferative and apoptosis inducing effect of allium atroviolaceum bulb extract on breast, cervical, and liver cancer cells," Frontiers in Pharmacology, vol. 8, p. 5, 2017.

[29] H. Zhu, G. Lv, Q. Qu, J. Xu, L. Zhang, and Y. Zhu, “Thunder god vine extract exerts antiproliferative effects on growth of human colon cancer cells and inhibits colon cancer growth in xenograft mice models," South African Journal of Botany, vol. 115, pp. 18-23, 2018.

[30] J. W. Choi, J. Lee, S. C. Kim et al., "Glucuronorhamnoxylan from capsosiphon fulvescens inhibits the growth of HT-29 human colon cancer cells in vitro and in vivo via induction of apoptotic cell death," International Journal of Biological Macromolecules, vol. 124, pp. 1060-1068, 2019.

[31] Y. Cao, F. Dai, Y. Li, L. Jia, Y. Luan, and Y. Zhao, “The research on the mechanism of Tsoong inhibiting for colon cancer," Saudi Journal of Biological Sciences, vol. 26, no. 3, pp. 605-613, 2018.

[32] K. Labbe and M. Saleh, "Cell death in the host response to infection," Cell Death and Differentiation, vol. 15, no. 9, pp. 1339-1349, 2008.

[33] M. Lamkanfi, T.-D. Kanneganti, P. Van Damme et al., “Targeted peptidecentric proteomics reveals caspase-7 as a substrate of the caspase-1 inflammasomes," Molecular \& Cellular Proteomics, vol. 7, no. 12, pp. 2350-2363, 2008.

[34] C. E. Haro and F. G. Fernández, "Necrotic death as a cell fate," Genes \& Development, vol. 20, no. 1, pp. 1-15, 2006.

[35] B. Mo Kim, "The implications of several forms of programmed necrosis for cancer therapy," Journal of Cancer Science \& Therapy, vol. 9, no. 9, pp. 630-635, 2017.

[36] S. W. G. Tait, G. Ichim, and D. R. Green, "Die another way non-apoptotic mechanisms of cell death," Journal of Cell Science, vol. 127, no. 10, pp. 2135-2144, 2014.

[37] G. Kanimozhi and N. R. Prasad, Anticancer Effect of caffeic acid on human cervical cancer cells. Coffee in Health and Disease Prevention, Elsevier Inc.,, Amsterdam, 2014.

[38] M. K. Swamy, U. R. Sinniah, and A. Ghasemzadeh, "Anticancer potential of rosmarinic acid and its improved production through biotechnological interventions and functional genomics," Applied Microbiology and Biotechnology, vol. 102, no. 18, pp. 7775-7793, 2018.

[39] "National Cancer Institute [NCI], 2019," https://www. cancer.gov/publications/dictionaries/cancer-drug/def/ eicosapentaenoic-acid.

[40] A. Ogo, S. Miyake, H. Kubota et al., "Synergistic effect of eicosapentaenoic acid on antiproliferative action of anticancer drugs in a cancer cell line model," Annals of Nutrition and Metabolism, vol. 71, no. 34, pp. 247-252, 2018.

[41] J. Li, Z. Gu, Y. Pan et al., "Dietary supplementation of $\alpha$-linolenic acid induced conversion of n-3 LCPUFAs and reduced prostate cancer growth in a mouse model," Lipids in Health and Disease, vol. 16, no. 1, pp. 1-9, 2017.
[42] W. Li, M. Zheng, S. Wu et al., "Benserazide, a dopadecarboxylase inhibitor, suppresses tumor growth by targeting hexokinase 2," Journal of Experimental and Clinical Cancer Research, vol. 36, no. 1, pp. 1-12, 2017.

[43] J. E. Lee, E. Giovannucci, C. S. Fuchs, W. C. Willett, S. H. Zeisel, and E. Cho, "Choline and betaine intake and the risk of colorectal cancer in Men," Cancer Epidemiology Biomarkers and Prevention, vol. 19, no. 3, pp. 884-887, 2010.

[44] X. Liu, W. Yang, Z. Guan et al., "There are only four basic modes of cell death, although there are many ad-hoc variants adapted to different situations," Cell and Bioscience, vol. 8, no. 1, pp. 1-12, 2018.

[45] W. Sha, Y. Zhou, Z.-Q. Ling, G. Xie, X. Pang, and P. Wang, $\mathrm{X}$. Gu, "Antitumor properties of salvianolic acid B against triplenegative and hormone receptor-positive breast cancer cells via ceramide-mediated apoptosis," Oncotarget, vol. 9, no. 91, pp. 36331-36343, 2018.

[46] C. Seidel, M. Schnekenburger, M. Dicato, and M. Diederich, "Antiproliferative and proapoptotic activities of 4-hydroxybenzoic acid-based inhibitors of histone deacetylases," Cancer Letters, vol. 343, no. 1, pp. 134-46, 2014.

[47] X.-N. Wang, K.-Y. Wang, X.-S. Zhang, C. Yang, and X.-Y. Li, "4-hydroxybenzoic acid (4-HBA) enhances the sensitivity of human breast cancer cells to adriamycin as a specific HDAC6 inhibitor by promoting HIPK2/P53 pathway," Biochemical and Biophysical Research Communications, vol. 504, no. 4, pp. 812-819, 2018.

[48] X. Zhang, D. Lin, R. Jiang, H. Li, J. Wan, and H. Li, "Ferulic acid exerts antitumor activity and inhibits metastasis in breast cancer cells by regulating epithelial to mesenchymal transition," Oncology Reports, vol. 36, no. 1, pp. 271-278, 2016.

[49] J. Gao, H. Yu, W. Guo et al., "The anticancer effects of ferulic acid is associated with induction of cell cycle arrest and autophagy in cervical cancer cells," Cancer Cell International, vol. 18, no. 1, pp. 1-9, 2018.

[50] P. Bhatt, G. S. Joseph, P. S. Negi, and M. C. Varadaraj, “Chemical composition and nutraceutical potential of Indian borage (Plectranthus amboinicus) stem extract," Journal of Chemistry, vol. 2013, pp. 1-7, 2013.

[51] R. Hemalatha, P. Nivetha, C. Mohanapriya, G. Sharmila, C. Muthukumaran, and M. Gopinath, "Phytochemical composition, GC-MS analysis, in vitro antioxidant and antibacterial potential of clove flower bud (Eugenia caryophyllus) methanolic extract," Journal of Food Science and Technology, vol. 53, no. 2, pp. 1189-1198, 2016.

[52] S. S. El-hawary, R. H. El-sofany, A. R. Abdel-Monem, and R. S. Ashour, "Phytochemical screening, DNA fingerprinting, and nutritional value of Plectranthus amboinicus (Lour.) Spreng," Pharmacognosy Journal, vol. 4, no. 30, pp. 10-13, 2012.

[53] J. R. Shubha and P. Bhatt, "Plectranthus amboinicus leaves stimulate growth of probiotic 1. plantarum: evidence for ethnobotanical use in diarrhea," Journal of Ethnopharmacology, vol. 166, pp. 220-227, 2015.

[54] N. Borhani, M. Manoochehri, S. Saleh Gargari, M. Ghaffari Novin, A. Mansouri, and M. D. Omrani, "Decreased expression of proapoptotic genes caspase-8- and BCL2 -associated agonist of cell death (BAD) in Ovarian cancer," Clinical Ovarian and Other Gynecologic Cancer, vol. 7, no. 1-2, pp. 18-23, 2015. 